\title{
State Education as High-Yield Investment: Human Capital Theory in European Policy Discourse
}

\section{Donald Gillies}

Abstract: Human Capital Theory has been an increasingly important phenomenon in economic thought over the last 50 years. The central role it affords to education has become even more marked in recent years as the concept of the 'knowledge economy' has become a global concern. In this paper, the prevalence of Human Capital Theory within European educational policy discourse is explored. The paper examines a selection of policy documents from a number of disparate European national contexts and considers the extent to which the ideas of Human Capital Theory can be seen to be influential. In the second part of the paper, the implications of Human Capital Theory for education are considered, with a particular focus on the possible ramifications at a time of economic austerity. In problematizing Human Capital Theory, the paper argues that it risks offering a diminished view of the person, a diminished view of education, but that with its sole focus on economic goals leaves room for educationists and others to argue for the educational, social, and moral values it ignores, and for the conception of the good life and good society it fails to mention.

Key words: human capital theory, policy, discourse, knowledge economy, neoliberalism

\section{Introduction}

Since its formulation in the early 1960s, Human Capital Theory has developed into one of the most powerful theories in modern economics. The growth of the concept of the 'knowledge economy' in the last 15 years has also afforded it a further degree of importance because of the strong connections it sees between education and training and economic growth. Where economic activity becomes focused on knowledge, on intellectual rather than physical labour, then the importance of education to that economy seems 
all the more crucial. Human Capital Theory thus lays considerable stress on the education of individuals as the key means by which both the individual accrues material advantage and by which the economy as a whole progresses. In a simple equation, the more and better education that individuals possess, the better their returns in financial rewards and the better the national economy flourishes.

Human Capital Theory has thus promoted education to a key instrumental role in boosting economic growth. The better the investment made by individuals in education, the better they and the economy will do. This elevated status, however, is not without its problematic aspects. There is a risk of education being narrowed to economic goals, of the broader aims and purposes of education being submerged, and of the person being reduced merely to 'human capital', not as a life to be lived, but as mere economic potential to be exploited.

In this paper, the prevalence of Human Capital Theory in educational policy across Europe is explored, followed by a fuller conceptual consideration of the implications of the theory for education. In this problematization, the possible effects on education of Human Capital Theory in times of economic crisis and austerity are given particular attention.

\section{Human Capital Theory}

The source of Human Capital Theory is usually traced to the work of two key theorists: Theodore Schultz (1902-98) and Gary Becker (b.1930). Both figures are associated with the 'Chicago School' of neoliberal thought and each won the Nobel Prize for Economics, Schultz in 1979 and Becker in 1992. The origins of the modern conception of the term can, however, be attributed to another US economist, Jacob Mincer (1922-2006), a mere Nobel nominee, who used the concept in a journal article more than 50 years ago [Mincer 1958]. The theory triggered a flurry of academic, political, and economic activity throughout the 1960s, suffered something of a depression for a time, before re-emerging with significant vigour in the last 20 years. It can now be seen as the dominant global theory in relation to the relative positions of education systems and the economy, albeit now being evidenced in varied guises.

There are, essentially, two key elements to the theory. The first relates to theorising that wage differentials or income distribution can be causally connected to education (in this case understanding the term as including schooling, tertiary education, training, and professional development). Much of the early research within Human Capital Theory looked at how earnings could be linked to educational experience: in its simplest form, 
longitudinal studies compared the earnings of high school graduates as opposed to college graduates in the USA [Mincer 1958, 1974]. Schultz [1960, 1962], noting that college graduates earned more, argued that in this sense the costs of a college education could be viewed as an investment which offered later returns in the form of relatively higher wages. His work is commendably clear and readable and he states the essence of Human Capital Theory simply (albeit in the sexist terminology of the age): I propose to treat education as an investment in man and to treat its consequences as a form of capital. Since education becomes part of the person receiving it, I shall refer to it as human capital [Schultz 1960: 571].

Research showed that there was a financial return for the time and resources dedicated to education and training and so families and individuals could be interpreted as undertaking these as a form of investment which would pay dividends later in the form of higher earnings. Education, therefore, was no longer to be viewed as 'consumption' but as investment [Blaug 1976].

The second key element in early Human Capital Theory is related to this finding. Whereas classical economics had tended to view the workforce in purely quantitative terms, Human Capital Theory introduced a qualitative aspect. Education and training were the seen as the most important ways in which the quality of the workforce could be enhanced. College graduates did not earn more by chance: it was because of the quality of their work that they earned more. Thus, education and training yielded broader economic returns than individual earning power. There were generic economic benefits for society which accrued from a well-educated and well-trained workforce. Just as individual choices about education and training could be understood in relation to judgements about likely returns on such investment, so at a national level the education system could be justified in the light of likely returns in the form of economic growth.

It was this second aspect of Human Capital Theory that had the greatest political effect, as can be imagined. Schultz [1962] suggested that the rapid recoveries of both Japan and Germany after World War II could be more easily explained if one took note of the pre-existing high levels of human capital in these well-educated countries. Becker [2002] later argued a similar case in relation to the global recovery from Black Monday in 1987. Developing human capital was therefore an important way in which economies could grow, and, indeed, survive or recover from setbacks. Becker [1992] argued that, outside of the Eastern bloc, human capital investment in the form of educational opportunities was central to those countries experiencing faster economic growth from 1960. In its appropriated form, the theory was thus held to be able to account for economic growth per se [Olssen et al. 2004: 147]. 
Some theoretical criticism of Human Capital Theory and the downturn of the 1970s combined to cast later doubt on its validity. Schultz himself [1971] sought to clarify that because of the 'long gestation period' between educational investment and economic return it was 'absurd' to think that sudden crises in relation to inflation or deflation could be tackled by turning on and off the education tap. Nevertheless, with the emergence of Ronald Reagan and Margaret Thatcher, Human Capital Theory found new champions and it returned to the political stage, before reaching international stardom following the collapse of the Soviet empire and the apparent triumph of western capitalism.

Gary Becker [1964, 1972, 1975, 1992, 1993, 2002a, 2002b], however, had sought to develop Human Capital Theory in a particular neoliberal way. Concentrating primarily on individual decision-making in relation to personal educational investments, Becker fused the theory with rational choice theory and began to explore its explanatory potential in a whole range of social activities previously untouched by economics such as the family and marriage. It was this enhanced focus on the individual, on the power of individual choice, that chimed with the neoliberal politics of the Reagan years. As Foucault [2008] argues, this represents a fundamental break with previous understandings. The worker moves from being an 'object' of economic analysis to being an 'active' economic subject [223], and from being a partner in economic exchange to being an entrepreneur, an entrepreneur of the self: the self now being understood as capital, and so the producer and source of earnings [226]. Becker's analysis, therefore, shifted paradigmatically from economics in terms of a relational mechanism between things or processes within a social structure, to the analysis of an activity - the internal rationality governing an individual's choices and behaviour [222-23].

In recent times, the definition of human capital has widened somewhat so that it is not simply knowledge or skills but also 'competencies', 'attributes', and 'attitudes' such as 'reliability, honesty, self-reliance, and individual responsibility' [Becker 2002b: 6]. Education remains centre stage, however, as the key factor in forming such human capital, which itself remains crucial for 'economic success' [Gurria 2007].

\section{Methods}

In considering the prevalence and sweep of Human Capital Theory within education policy, this paper examines a snapshot sample of recent policy documents from a variety of European educational contexts. Documents examined include official government policy texts from several national systems and from related bodies: the education systems sampled are those of 
Scotland, England, Wales, Northern Ireland, Eire, Norway, Sweden, Denmark, Finland, Germany (and Bavaria), Austria, Slovakia, and the Czech Republic, as well as documents from the European Union and from the OECD (Organisation for Economic Co-operation and Development). Two factors guided the selection of sources: the first was aim of presenting a broad sweep of the European continent, sampling a wide variety of different national contexts; the second was a constraining factor in that this sample was wholly dependent on the availability of suitable policy documents in translation on these official websites. The selection of the documents themselves was based on the aim of analysing significant policy texts currently operational. Occasionally, for contextual purposes, older texts have also been cited to show progression or change or a historical pattern.

The analysis took the form of a critical linguistic survey - an exercise in deductive discourse analysis - a means by which key words and concepts typical of Human Capital Theory, as understood above, were sought in the chosen policy texts. Fairclough's tripartite model of discourse analysis which examines textual, discursive, and social aspects is a useful means to approach the analysis of policy texts [Fairclough 1992]. At the textual level, the analysis involves close linguistic examination; at the discursive level, more is made of the rhetorical and other means by which the text achieves and aims at certain ends; at the social level, the analysis relates the language, concepts and style of the text to broader social and political contexts, in particular the way in which the text reflects ideological beliefs and suppositions, assumptions, and power relations. This study fuses Fairclough's textual and social levels in that linguistic evidence is identified which can be seen as indicative of theory operating at wider social and political levels. In doing so, it seeks to expose, and problematize, the extent to which Human Capital Theory can be seen as influential within the rationality of government, the governmentality evidenced within the selected documents [Foucault 1991].

In this study, Fairclough's concepts of discourse and social practice have also been utilised. Thus, Human Capital Theory is here conceptualized as a discursive process which both represents and constitutes state education, understood as a social practice [Fairclough 2003: 206-209]. Human Capital Theory aims to construct state education in a particular way, both indicatively and normatively. As such, it can be understood as rationalising a particular social imaginary. This imaginary interpellates subjects - educational actors - into new ways of being and it is in this subjectivisation that the link to Foucauldian thought can be further established. The theory positions actors in a particular way, understanding themselves and acting on themselves, and others, as 'human capital'. This is central to neoliberal gov- 
ernmentality and the notion of the self as enterprise [Foucault 2005; Rose 1999; Miller, Rose 2008; Gillies 2011].

Foucault's concept of problematization has served as the framework for the discussion of the findings in this study. This approach eschews a right/ wrong binary and instead deploys critique to probe, challenge, and question what is offered as essential, self-evident, or necessary [Foucault 1984; 2002].

Some limitations of the study need to be acknowledged: as indicated above, it depends on materials available on national education ministry websites; it depends, further, on the available English translations of such material; there is no sense of equivalence in terms of the documents analysed in the different national contexts; and, it has operated at the textual level with no attempt to probe empirical reality in schools and classrooms, nor the lived experience of teachers and learners alike.

\section{Human capital theory and education policy: findings}

Within the countries of the UK, the place of Human Capital Theory has been central within education, particularly so in England during the BlairBrown administrations 1997-2010. The alignment of education to the knowledge economy was a central plank of New Labour policy. As Tony Blair famously said 'education is the best economic policy we have' [DfEE 1998: 1]. Human Capital Theory was central to New Labour's Third Way project of founding economic success on the knowledge economy [Giddens 2000] and through the concept of 'the social investment state' [Giddens 1998], by which the state aims to cultivate human capital. This belief that economic success could be built on the capacity of the state education system to produce skilled knowledge workers was an early core tenet of New Labour thinking even prior to government and gave rise to press ridicule of Gordon Brown's 1994 reference to 'post-neoclassical endogenous growth theory'. This theory holds that long-run economic growth can be built on government investment decisions, specifically in relation to educational outcomes [Crafts 1996]. New Labour's first white paper on education [DfEE 1997: 3] was quite explicit about the theoretical basis of government policy: 'We are talking about investing in human capital in the age of knowledge. To compete in the global economy, to live in a civilized society and to develop the talents of each and every one of us, we will have to unlock the potential of every young person'. In recent times, with the change of government the rhetoric has also shifted but, even so, when introducing the new education bill for English schools, the Secretary of State for Education clearly signalled the context within which proposed legislation was placed; '...it is only by 
radically and fundamentally reforming our education system and learning the lessons of the highest performing nations that we can generate the longterm economic growth on which prosperity depends...' [Gove 2011].

In Scotland, following devolution in 1999, the New Labour project was somewhat muted because of the personnel involved, the different political context, and because of the need for parliamentary alliance with the Liberal democrats. However, the strong economic focus of the education system remained clear and this was continued by the Scottish National Party who first took power as a minority government in 2007. Their strategic purpose - 'creating a more successful country, with opportunities for all of Scotland to flourish, through increasing sustainable economic growth' [Scottish Government 2011a]- has been summarised in their education policies as aiming for a 'smarter' Scotland by which is meant shaping the education system for global economic advantage. This is a not uncommon competitive policy objective - 'to outsmart other countries in the development of the nation's human resources' [Brown 2001: 9]. Improving skills is seen as key to this and again this is expressed in human capital terms - 'our people are Scotland's greatest resource. That's why we are investing in our current and future workforce...' [Scottish Government 2011b]. The most recent review of teacher education in Scotland, commences with this perspective clearly established: 'Over the past 50 years, school education has become one of the most important policy areas for governments across the world. Human capital in the form of a highly educated population is now accepted as a key determinant of economic success' [Donaldson 2010: 2].

In Northern Ireland, recent changes such as the establishment of a central Education and Skills Authority have focused on 'pupil outcomes' but these have not been expressed solely in human capital terms. The concept appears to be broad and inclusive, while recognising economic aspects, as in the recent drive on literacy and numeracy: 'This strategy is therefore of vital importance as children who leave school with inadequate literacy and numeracy skills face a lifetime of difficulty and disadvantage. I have previously met with employers and business leaders who have told me how important these skills are in today's competitive marketplace. They are also vital for everyday living in a global community' [Ruane 2008]. The major school improvement document, however, does place an emphasis on the school/global economy relationship: 'Society is changing rapidly and we must respond to that change to best meet the needs of our children and young people, who will need the skills to take their place in an increasingly global economy, here or elsewhere' [DENI 2009: 1]. The competitive aspect of the global economy is also recognised in a section seeking to benchmark Northern Ireland's school outcomes with those of other national economies: '...we should 
be benchmarking ourselves rather more ambitiously and in an international context. It is after all from across the globe that our young people will have to face challenges and compete in tomorrow's economy' [8].

In Wales, the Welsh Assembly Government has focused its strategic agenda around 'The Learning Country', a document originally prepared in 2001 which sets some core objectives for the education system. It is comprehensive in nature and, while embracing economic purposes and explicitly conscious of such influences as PISA and the Lisbon agenda, cannot be said to have fully adopted Human Capital Theory language: 'The Welsh Assembly Government wants Wales to be a place where high quality, lifelong learning liberates talent, extends opportunities, empowers communities, provides better jobs and skills to enable people to prosper in the new economy and creates a sustainable future for our country. Through our education and training policies, we aim to raise levels of achievement and empower children, young people and adults to achieve social and economic well being. We are taking forward a far-sighted, ambitious agenda for education and lifelong learning. We want to rival the best in the world' [DELLS 2008].

In Ireland, there is also this recognition of the global market: 'there is a pressing need to adapt and reform the structures and improve the performance of the education system to meet current social and economic needs and to rank with the best performing education systems..., demand for postschool education and training has increased sharply in response to labour market conditions' [DES 2011a: 8]. There is a strong sense of Ireland positioning its educational system and outcomes in this international context. The political ambition ' is for Ireland to become a global leader in the provision of high-quality education to the next generation of leaders, entrepreneurs, and decision-makers, who will make a difference in their own countries and who will form vital networks of influence for Ireland' [Educationireland 2010: 7]. The strategy sees international education as a major form of economic enterprise in itself [31] but the overall policy direction for higher education has an explicit economic focus, and a firm commitment to the ideas of Human Capital Theory, drawing on the earlier work of Kavanagh and Doyle [2006]: 'higher education is central to future economic development in Ireland' [DES 2011b: 3]. Indeed, it is tasked with generating the recovery from the global economic crisis which hit Ireland hard: it 'has a critical role to play in the coming decades as we seek to rebuild an innovative knowledge-based economy that will provide sustainable employment opportunities and good standards of living for all our citizens' [8] and 'If Ireland is to achieve its ambitions for recovery and development within an innovationdriven economy, it is essential to create and enhance human capital by expanding participation in higher education'[10]. 
The concept of (young) people as valuable 'resources' or 'assets' which need to be invested in, essentially for national economic returns, is one that recurs across European education policy discourse. Not surprisingly, perhaps, given its specific economic purpose, the OECD and its secretarygeneral very strongly endorses this view: 'All societies must invest in their most valuable asset: their people' [Gurria 2008]. The OECD has firmly embraced Human Capital Theory, and has been very active in promoting the idea that education is vital for economic growth because of its role in the development of human capital [OECD 1996a, 1996b, 1998, 2001, 2002, 2005; Pissarides 2000; Cohen, Soto 2001; CERI, 2004; Keeley, 2007]. Within the EU, the very clear strategy of competing globally with the North American and Asian economic blocs entails encouraging member states towards '...increasing investment in human capital through better education and skills' [Commission of the European Communities 2008: 2]. This is hardly surprising in the light of the Lisbon agenda which committed EU states to becoming more dynamic and competitive, with a focus on jobs and growth in 'a knowledge-based economy'. The new EC Europe 2020 strategy also uses the term 'smart growth' for the emphasis on aligning education with the perceived demands of a knowledge economy, and as a means of competing with the US and Asia [Room 2005].

In the Czech Republic, while there are instances of this more functional language - 'key competencies', for example - the aims of the state education system are presented in less blunt terms : 'pupils gradually acquire such personal qualities that will enable them to continue their studies, acquire additional skills in their profession of choice and continue their lifelong learning, and - to a degree matching their potential - to actively participate in the life of the community and society' [MoEYS 2007]. In Slovakia, the influence of Human Capital Theory is more patent. 'Slovakia's capability of effectively utilising and fostering its human potential is a precondition for its economic and social, as well as moral and cultural, success...The main criterion the Government will follow when changing the compulsory curriculum is the development of an active citizen capable of succeeding in an international labour market...' [Slovak Government 2010].

In Denmark, educational reforms are also positioned in a similar context: The aim is to create a world-class education system and have everyone participate in lifelong learning. It shall help develop Denmark as a leading knowledge society in a globalised world' [Undervisnings Ministeriet 2007]. In Finland too 'Education is a key factor for competitiveness' [Opetusministeriö 2009] but there is also a recognition of its role in securing the 'social welfare of Finnish society' and of ' a civilisation in which every individual can grow 
as a person according to their own abilities and aptitudes...' [Opetusministeriö 2004: 15].

In Norway, government reports point out that 'the need for a labour force with only primary and secondary education is low', and so 'more people must complete their education so that they can join the labour market and gain a secure footing in working life', recognising that 'enhanced human capital and skills ...have direct economic effects'. This is bluntly acknowledged: 'People are society's most important resource' and one of the government's most important priorities is 'to invest in education and knowledge' [Regjeringen 2009]. Yet education is recognised as having wider aims: 'we need more knowledge and skills: both for addressing the increasingly complicated challenges in society and in order to evolve as human beings' [Kunnskapsdepartementet 2008].

In Sweden, despite recent developments which might be seen as having neoliberal roots, policy discourse appears not to have adopted Human Capital Theory concepts and terminology to any great extent. Education documents are much more replete with the language of democracy and humanist concerns. The main curriculum document [Skolverket 2006], for example, is more focused on such issues as values, understanding, compassion, fairness, harmonious living, and democracy. Nevertheless, there is evidence of its influence: Regeringskansliet [2011: 3], for example, revealingly states that 'The foundation of the Swedish reform programme has been that education enhances Sweden's competitiveness and improves individuals' skills and opportunities in life', and Puaca [2011] has highlighted a similar core theme within the country's lifelong learning strategy.

In Bavaria, the importance of human capital is very starkly expressed: "the raw material of a child's mind is the most valuable natural resource that we possess' [Bayerische Staatsregierung 2009]. The Federal Government also stresses the importance of this in relation to lifelong learning: 'life and work in the knowledge society and the special importance of developing human resources have already helped to enhance the reputation of lifelong learning'. The place of learning is clearly positioned also: that 'the competition for future opportunities for Germany has essentially become an international competition for the quality of education systems' [Federal Ministry of Education and Research 2009].

In Austria the new 'global curriculum' specifically positions Austrian education within a globalized market. The Education Minister explains: 'in all of our countries we are developing towards knowledge-based societies. Consequently, investing in human and social capital becomes crucial for the competitiveness of our economies; for all educational systems this poses a major challenge“ [Schmied 2010]. 


\section{Human capital theory and education policy: discussion}

It is clear from even a cursory glance at government policy across Europe, that education has a highly elevated status. In that sense, for those involved in education, for parents, for children, and for young people, it is perhaps with some satisfaction or relief that they may view the central, strategic importance of education at national and supranational levels. However, that very political focus may prove to have a Faustian edge: education, filtered as it is by Human Capital Theory, is largely constructed in one particular sense - as instrumental to the economy - and so conceptualized quite differently from how it has been widely understood in the past and, perhaps, in the vernacular. While Human Capital Theory has thrust education into the political limelight, it is education in one particular role only and its continued central importance relies almost entirely on its capacity to continue to be seen as economically vital. Education may not the first to find that fame has its costs.

From its very earliest days, however, human capital theory has been controversial. Even its central theorists recognise this issue. Schultz [1960: 572] acknowledges that the concept may be considered 'repugnant' by some because of the way it sees education in such narrow economic terms. Thus, he is at pains to stress that 'my treatment of education will in no way detract from, or disparage, the cultural contributions of education'. Similarly, Schultz [1961: 2] accepts that some may find it 'offensive' to talk about humans as mere 'capital goods'. Becker [1993] defends Human Capital Theory as simply a 'method' of analysis [385] but duly admits that, for many, 'to approach schooling as an investment rather than a cultural experience was considered unfeeling and extremely narrow' [392]. He had earlier conceded that there was also what he termed 'psychic gain' from a college education [Becker 1975: 198] and in his later work broadens out the concept of 'human capital' to include such things as economically relevant attitudes and characteristics [Becker 2002b]. This 'capitalization' of the human leads to the position that even 'relationships and shared values in societies can be seen as a form of capital that makes it easier for people to work together and achieve economic success' [Keeley 2007: 11]. The human, even in its most basic social interactions, is for the economic.

These, then, represent two significant challenges for Human Capital Theory: that it diminishes the concept of the human and that it diminishes the concept of education. As Block [1990] argued, but a point often overlooked in human capital discourse, it is not human beings who are inputs in the production process but 'one of their characteristics - their capacity to do work'. There is a reductivist tendency within Human Capital Theory to view 
people as simply 'a bundle of technical skills' [Brown 2001: 13]. There is also a moral question around conceptualising humans as resources or assets to be exploited, or profited from.

The development of Human Capital Theory in relation to rational choice theory also fails to take account of motivation in human behaviour, other than for personal advantage. The idea of an altruistic motive, or being motivated by the public good, or concern for others, is essentially denied by its adherents. The notion of 'public interest' is interpreted as merely a cloak for self-interest, and the idea of 'public duty' dismissed as delusion [Buchanan 2007]. Even in relation to career development, issues around job satisfaction, challenge, enjoyment, status and so on are all absent from the account [Blaug 1976]. The model also assumes that all further education is geared for the labour market [Olssen, Codd, O'Neill 2004: 148] and so cannot account for the expansion of educational activities within the retired population for whom there cannot be any hope of financial benefit accruing, nor of employment advantage.

For all Becker's insistence that there is more to education than the production of economic potential, his understanding of schooling and education is unmistakably narrow. He defines a 'school' as 'an institution specializing in the production of training' [Becker 1962: 25] and has recently promoted online learning as a much more flexible and cost-effective educational medium, without any sense of what might be lost from erasing school as a public place and schooling, learning, education as a social activity. It is life as zoē, rather than bios: life as mere existence as opposed to life as a social being [Harris 2007: 24].

Of course, it would be wrong to see Human Capital Theory as necessarily involving such a narrow view of education. Nevertheless, there is a tendency within the theory for a very pared-down model of education to be presented. Education - and so prosperity - becomes entirely focused on the human as an individual unit and on education as solely a matter of individual choices [Brown, Lauder, Ashton 2007: 132]. This has been rejected as 'superficial' [Bowles, Gintis 1975: 78], partly because it leaves as entirely unproblematic the nature of the system, and the nature of the socioeconomic, cultural, and political context which has shaped and continues to shape educational provision and experience. Issues around reproduction, class, power, and dominance are ignored [Bourdieu 1986: 244]. Fundamental inequity is entirely elided in the Human Capital Theory model: any inequalities of outcome can be attributed to the shortcomings of individuals in respect of their choices or capital returns. The overarching economic, social, and political system is essentially absent from any analysis, far less criticism.

The lack of self-awareness on this issue by human capital theorists can 
be illustrated by Schultz's criticism of some US education policies on school catchment areas and intake regulations as 'social engineering' [Schultz 1981], oblivious to the fact that whole system has been politically engineered, and that schooling for economic returns is also an 'engineered' phenomenon. This is indicative of a general approach that sees market capitalism as an uncomplicated norm, a natural arrangement of affairs above and beyond human concern.

One of the most contested issues in relation to the conception of education within Human Capital Theory is that it presents education as instrumental for economic growth or economic 'success', without ever indicating what this economic development is for. The theory essentially makes an abrupt stop at this point as if economic growth were an end in itself. It is this gap that means that issues around education and values re-emerge as crucial [Sen 1999]. Even if economic growth is accepted as a 'good', it remains to be argued what it is good for [Galbraith 1996: 69; Weiss 1995: 151; Ozga, Lingard 2007: 68; Rizvi, Lingard 2010: 81]. There still remains a significant role for education, therefore, to explore its age-old concerns with the more abundant life, with democracy, society, citizenship, happiness, and fulfilment.

Human Capital Theory does present at least two issues which can be used to advantage even by its critics. One is the central role afforded to teachers as those who help create and develop human capital. Far from being minor public servants cocooned from the harsh realities of tooth and claw capitalism, teachers now become repositioned as key figures in developing the human capital necessary for the goal of economic growth. The OECD [2005] has made this a major focus of attention and 'teacher quality' has also been given centre stage by McKinsey [2007]. The importance of teaching is a concept, however, that is open to a number of different moral and political viewpoints. Rikowski [2001], from a Marxist perspective, argues that this very space allows opportunities for 'radical pedagogy' to challenge dominant thinking, to raise questions, and so help learners become critically engaged with the system, society, and their own position. This highlighting of the agency of the teacher, therefore, should be a boost to the profession; however it chooses to employ it.

The second issue is that Human Capital Theory clearly positions education as both an individual and a public good. The theory holds that the returns on education investment are both personal and social. The individual is rewarded financially and the economy as a whole is boosted by individuals with advanced human capital [Schultz 1960; Becker 2002a]. At a time when government is questioning its role in funding higher education in relation to tuition and maintenance fees, this presents a powerful challenge, if proponents of Human Capital Theory choose to exploit it. While others 
from liberal-humanist positions would advance other arguments in favour of publicly-funded higher education, the arguments of Human Capital Theory may prove valuable allies. The danger is, of course, as is being experienced in a number of higher education institutions, unless some very crude economic link can be established, then subjects and studying within the arts and humanities, in particular, may come to be questioned. Human Capital Theory is, therefore, something of a mixed blessing in relation to his argument, depending on how it is formulated.

This paper does not consider in depth the particular argument which centres on the explanatory economic power of Human Capital Theory. There is a long-established debate within economics which addresses a whole range of contested issues around the theory and its variants. Only a very few questions will be raised here. The first of these is that that without the concomitant 'creation of growth-enhancing jobs' [Pissarides 2000], it is not obvious that human capital development has positive national economic impacts [Blaug 1987]. For example, the history of many economies can be seen in terms of the export of human capital because of the lack of a supportive economic context. While one could argue in global terms that such human capital was of generic value, it is not clear how the economies of Ireland, Scotland, mid- $20^{\text {th }}$ century India, and post-1989 Eastern Europe, for example, benefitted from producing, and exporting, countless graduates. The same will be true of any similar economy where an advanced education system resides within a weak or undeveloped economic context. In the current climate, rather than a force for economic growth, educational qualifications may be better understood as a form of 'defensive expenditure' in the hope of securing any job at all, as education provides diminishing returns and reduced positional advantage [Brown, Lauder 2006: 325]. Secondly, the differential financial return on investments in education which favour graduates can also be interpreted in relation to the decline in earning power of unqualified workers, especially in the 1980s [Brown 2001: 20]. Thus, it is not so much that educational qualifications derive benefit but that lack of qualifications derives loss.

A further economic argument centres around the idea that educational qualifications do not themselves endow the individual with relevant human capital but that they merely act as a 'signal' to employers [Weiss 1995; Kjelland 2008]. Indeed, it is now recognised that while educational qualifications may signal evidence of human capital, they say nothing explicitly about work ethic, for example. Thus, later conceptions of human capital have broadened out to encapsulate issues around attitude and other attributes [Becker 1993, 2002b; OECD 2002], which are also seen as key factors. 
Finally, in relation to economic debate, it would be perverse not to mention Marxist critiques of Human Capital Theory, a theory which has, after all, appropriated a key term in Marxist thinking. There is a rich seam of criticism directed at Human Capital Theory from a Marxist perspective, which typically argues against the absence of the notion of social class, the failure to recognise value and surplus value within the Human Capital Theory mod$\mathrm{el}$, the elision of the labour/labour-power distinction, and the failure to recognise labour relations within the workplace nexus. In addition, of course are the many omissions in Human Capital Theory at the macro level in relation to ownership, power, domination, reproduction, inequality, and the economic system [Bowles, Gintis 1975; Rikowski 1999, 2001, 2005, 2007; McLaren, Rikowski 2001; Allman, McLaren, Rikowksi 2005].

\section{Human capital theory and education in austere times}

The banking crisis of 2008 and the consequent economic woes of a number of national economies has brought with it significant challenges for the public sector in general and for education in particular. It may be noted in passing that it was not unskilled workers, the illiterate, the innumerate, or the unemployable who succeeded in destroying the banking system and with it the integrity of several major western economies, but rather those with most human capital, the most highly qualified, and highly paid, knowledge workers in society. How this squares with Human Capital Theory, is for others to determine.

The attempts in several western economies to address the crisis through reducing public sector costs threaten to create a number of problems for an education system, conceived of in Human Capital Theory terms. The view that economic woes can be tackled through the re-focusing of the education system could lead to a number of challenges for the education sector. In austere times, it is likely that reduced resources will tend to be concentrated in areas seen as most closely linked to the economy. This can be seen most starkly in relation to higher and further education where considerable pressure has been exerted on the arts, humanities, and social sciences. Such disciplines which have no simple correlation to economic activity or growth become viewed as an expensive indulgence and their continued existence becomes dependent on attempts to demonstrate their economic importance rather than on any fuller conception of education [Nussbaum 2010].

In the schools sector, pressure on the curriculum tends to be more in relation to its focus as opposed necessarily to structure. The emphasis shifts from knowledge and disciplinary depth to transferable skills, and especially those seen as conducive to market profitability. As pressure to reduce costs 
in the private sector grows, industry increasingly looks to shift the costs of training to the education sector itself. Thus we have repeated calls from the Confederation of British Industry and similar employers' bodies about the quality of school leavers and college and university graduates in relation to employability. Such calls find a welcome audience in governments and major political parties, almost all of whom subscribe to variants of Human Capital Theory. When allied to the view that national economies need to compete in a global knowledge economy, it is easy to see how the demands to increase the quality of employability in young people become increasingly critical.

It is partly because of the costs of training and the risks of an untried workforce, that in austere times so many companies are relying on older workers. Youth unemployment is a concern across Europe as stagnating growth limits new job opportunities. This efficiency imperative thus means companies are reluctant to risk outlay on training costs, with variable returns, as opposed to the safer reliance on experienced workers. Where companies do recruit younger staff, the demand is that these be fully pre-trained, in school or college. This will undoubtedly put pressure on school curricula: if the goal is simply employability then there is a risk of narrowing the curriculum to skills for work and the concept of personal growth, or of development as 'whole' individuals is lost [OECD 2002: 119].

Schultz [1967] pointed out decades ago that the poor and disadvantaged represented the 'best unexhausted investment opportunities' compared to the rich and the middle class. In other words, the state had failed to exploit their potential sufficiently and, given their lowly status, the opportunity for high returns was considerable. However, the public investment required to counteract systemic inequality has proved to be much higher than the willingness of politicians to act, and the result has been that very little has been done to address this aspect of Human Capital Theory. Because it has been fused with rational choice theory, the focus in Human Capital Theory since has been on individuals and equality of opportunity rather than on equalising starting-points through socioeconomic adjustment. Klees [2008: 338-9] reports on a interesting study where even the targeted resources of Merrill Lynch were unable to make much impact on the problems of deep-seated socioeconomic disadvantage affecting potential college students. The danger is that in times of economic difficulties, governments will cut back even more on the sort of additional support required for less advantaged communities and individuals to improve their educational and vocational prospects. Crude credit balance approaches may override issues around equity, fairness, and access and it would not be surprising to see funding challenges around inclusion, special education, and related issues. It would seem 
important, therefore, that the concept of children's rights is kept uppermost in this context. Education for all, when founded on rights, is a much more principled and secure position when compared to one merely conditional on notional investment returns. Nevertheless, it is interesting that Human Capital Theory itself does afford an argument in relation to the waste, if not the injustice, of inequality, albeit framed in its own narrow terms.

\section{Conclusion}

Human Capital Theory has been shown to have an influential position in supranational bodies within Europe and within many national education systems. The picture across Europe is not uniform, however, and although it is evident in policy discourse this does not necessarily map on to social practice. What happens at school and institutional level may well not be so easily read as evidence of the dominance of Human Capital Theory.

Within economic policy it is highly important, however, as nation states and economic organisations strive for eminence within the new knowledge economy. The emphasis on it within OECD and EU documentation serves as a powerful steering mechanism across the European political landscape. This outlook places a great importance on education, but it is an attention that may have some risks for broader views of education, if education becomes solely viewed as instrumental to the economy and if, by extension, the only valued aspects of education become those which have direct economic, wealth-generating, impact.

Human Capital Theory with its focus on individual responsibility and individual choices also chimes well with the neoliberal shift from government to governance [Ball 2006: 132], with the concept of the self as entrepreneur [Foucault 2008], with 'perpetual training' [Deleuze 1992] and the related narrowing of the concept of lifelong learning, and with the willing subordination of national policy and agency, and of cultural and community values, to the assumed omnipotence of the market and globalization [Rizvi, Lingard 2010: 116].

Human Capital Theory is, however, open to a number of fundamental criticisms from an educational perspective. It can lead to a narrowed conception of education and a narrowed conception of the human. It fails to present any sort of normative picture of what economic success is for, it presents no picture of the good life, of the good society. As such, it leaves open a clear opportunity for educationists and others to argue for the educational, moral, and social values which have been lost sight of and which would give sense and meaning to economic life. A much richer and fuller understanding of the person can be presented to justify the educational experiences which a lib- 
eral, humanist outlook previously cherished and championed. The economist, J.K. Galbraith presented a similar view, at the end of a lifetime in economics: The good society cannot accept that education in the modern economy is primarily in the service of economics; it has a larger political and social role, a yet deeper justification in itself [Galbraith 1996: 69].

\section{References}

Allman, P., Mclaren, P., Rikowski, G. 2005. After the Box People: The Labour-Capital Relation as Class Constitution - And Its Consequences for Marxist Educational Theory and Human Resistance. In Mclaren, P. (Ed.), Capitalists and Conquerors: A Critical Pedagogy Against Empire. Lanham MD: Rowman \& Littlefield, 135-165.

Ball, S. 2006. Education Policy and Social Class. Abingdon: Routledge. Bayerische Staatsregierung. 2009. The Future Lies in Education [online], May, 2011 <http:// www.bayern.de/the-future-lies-in-education-.607.htm>

Becker, G. 1962. Investment in Human Capital: A Theoretical Analysis. In The Journal of Political Economy, 70 (5): 9-49.

Becker, G. 1972. Schooling and Inequality From Generation To Generation Inequality: Comment. In The Journal of Political Economy, 80(3): S252-S255.

Becker, G. 1975. Human Capital: A Theoretical and Empirical Analysis (2 ${ }^{\text {nd }}$ Ed.). New York: Columbia University Press.

Becker, G. 1992. Human Capital and the Economy. In Proceedings of the American Philosophical Society, 136 (1): 85-92.

Becker, G. (1993). Nobel Lecture: The Economic Way of Looking at Behaviour. In The Journal of Political Economy, 101(3), 385-409.

Becker, G. 2002a. The Age of Human Capital. In Lazear, E. (Ed.), Education in the $21^{\text {st }}$ Century. Stanford CA: Hoover Institution Press, 3-8.

Becker, G. 2002b. Human Capital [online], May, 2011 <http://www.um.edu.uy/ docs/revistafcee/2002/humancapitalbecker.pdf>

Blaug, M. 1976. The Empirical Status of Human Capital Theory: A Slightly Jaundiced Survey. In Journal of Economic Literature, 14(3): 827-855.

Blaug, M. 1987. The Economics of Education and the Education of an Economist. New York: New York University Press.

Block, F. 1990. Post Industrial Possibilities: A Critique of Economic Discourse. Los Angeles: University of California Press.

Bourdieu, P. 1986. The Forms of Capital. In Richardson, J.G. (Ed.). Handbook of Theory and Research for the Sociology of Education. Westport, CT: Greenwood Press, 241-258.

Bowles, S., Gintis, H. 1975. The Problem with Human Capital Theory - A Marxian Critique. In The American Economic Review, 65 (2): 74-82.

Brown, P. 2001. Skill Formation In the $21^{\text {st }}$ Century. In Brown, P., Green, A., Lauder, H. (Eds.), High Skills. Oxford: Oxford University Press, 1-55. 
Brown, P., Lauder, H. 2006. Globalization, Knowledge and the Myth of the Magnet Economy. In Lauder, H., Brown,P., Dillabough, J-A., \& Halsey, A.H. (Eds.), Education, Globalization and Social Change. Oxford: Oxford University Press, 317-340.

Brown, P., Lauder, H., Ashton, D. 2007. Education, Globalisation and the Future of the Knowledge Economy. In European Educational Research Journal, 7 (2): 131-156. Buchanan, J. 2007. Interview. In Curtis, A. (Producer), The Trap. London: BBC.

CERI. 2004. Innovation In the Knowledge Economy. Paris: OECD Publications. Cohen, D., Soto, M. 2001. Growth and Human Capital: Good Data, Good Results. Paris: OECD.

Commission of the European Communities. 2008. An Updated Strategic Framework for European Cooperation in Education and Training COM (2008) 865. Brussels: The Authors.

Crafts, N. 1996. 'Post-Neoclassical Endogenous Growth Theory': What Are Its Policy Implications? In Oxford Review of Economic Policy, 12 (2): 30-47.

Deleuze, G. 1992. Postscript on the Societies of Control. In October, 59: 4-7.

Department for Education and Employment. 1997. Excellence in Schools. London: Her Majesty's Stationery Office.

Department for Education and Employment. 1998. The Learning Age: A Renaissance for a New Britain. London: The Stationery Office.

Department for Education, Lifelong Learning and Skills. 2008. The Learning Country: Vision Into Action. Cardiff: Welsh Assembly Government.

Department of Education (Northern Ireland). 2009. Every School a Good School. Belfast: The Authors.

Department of Education and Skills (Eire). 2011a. Organisation and Current Issues. Dublin: The Authors.

Department of Education and Skills (Eire). 2011b. National Strategy for Higher Education to 2030 - Report of the Strategy Group. Dublin: The Authors.

Donaldson, G. 2010. Teaching Scotland's Future. Edinburgh: The Scottish Government.

Educationireland. 2010. Investing In Global Relationships. Dublin: Department of Education and Skills.

Fairclough, N. 1992. Discourse and Social Change. Cambridge: Polity Press.

Fairclough, N. 2003. Analysing Discourse. London: Routledge.

Federal Ministry of Education and Research. 2009. Innovation in Education [online], May, 2011 <http://www.bmbf.de/en/1076.php>

Foucault, M. 1984. What is Enlightenment? In Rabinow, P. (Ed.), The Foucault Reader. London: Penguin, 32-50.

Foucault, M. 1991. Governmentality. In Burchell, G., Gordon, C., Miller, P. (Eds.), the Foucault Effect. Chicago: University of Chicago Press, 87-104.

Foucault, M. 2002. Questions of Method. In Faubion, J. (Ed.), Michel Foucault: Power. London: Penguin, 223-38. 
Foucault, M. 2005. The Hermeneutics of the Subject: Lectures at the Collège De France 1981/1982. New York: Picador.

Foucault, M. 2008. The Birth of Biopolitics: Lectures at the Collège De France 19781979. Basingstoke: Palgrave Macmillan.

Galbraith, J.K. 1996. The Good Society. London: Sinclair-Stevenson.

Giddens, A. 1998. The Third Way: The Renewal of Social Democracy. Cambridge: Polity Press.

Giddens, A. 2000. The Third Way and Its Critics. Cambridge: Polity Press.

Gillies, D. 2011. Agile Bodies: A New Imperative in Neoliberal Governance. In Journal of Education Policy, 26 (2): 207-223.

Gove, M. 2011. Speech to House of Commons [online], May, $2011<\mathrm{http}: / /$ www. michaelgove.com/content/education_bill_second_reading>

Gurría, Á. 2007. Introduction. In Keeley,B. Human Capital: How What You Know Shapes Your Life. Paris: OECD.

Gurria, Á. 2008. A Brief Introduction to What We Do. [online], May, $2011<$ http:// www.oecd.org/dataoecd/57/7/41481091.pdf>

Harris, S. 2007. The Governance of Education. London: Continuum.

Kavanagh, C., Doyle, E. 2006. Human Capital and Productivity in the Irish Context. Dublin: Expert Group on Future Skills Need.

Keeley, B. 2007. Human Capital: How What You Know Shapes Your Life. Paris: OECD. Kjelland, J. 2008. Economic Returns To Higher Education: Signaling V. Human Capital Theory; An Analysis of Competing Theories. In The Park Place Economist, 16 (1): 70-77.

Klees, S. 2008. A Quarter Century of Neoliberal Thinking in Education: Misleading Analyses and Failed Policies. In Globalisation, Societies and Education, 6(4): 311-348.

Kunnskapsdepartementet. 2008. Education Strategy: Report No 44 To the Storting. Oslo: The Authors.

Mclaren, P., Rikowski, G. 2001. Pedagogy for Revolution Against Education for Capital: An E-Dialogue on Education in Capitalism Today [online], May, 2011 <http:// clogic.eserver.org/4-1/mclaren\&rikowski.html>

Miller, P., Rose, N. 2008. Governing the Present. Cambridge: Polity Press.

Mincer, J. 1958. Investment in Human Capital and Personal Income Distribution. In The Journal of Political Economy, 66: 281-302.

Mincer, J. 1974. Schooling, Experience, and Earnings. New York: National Bureau of Economic Research.

Ministry of Education, Youth and Sports. 2007. Framework Education Programme for Basic Education. Prague: VÚP.

Nussbaum, M. 2010. Not for Profit: Why Democracy Needs the Humanities. Princeton NJ: Princeton University Press.

Olssen, M., Codd, J., O’Neill, A-M. 2004. Education Policy. London: Sage. 
Opetusministeriö Ministry of Education. 2004. Education and Research 2003-2008. Helsinki: Ministry of Education.

Opetusministeriö Ministry of Education. 2009. Education [online], May, 2011 <http://www.minedu.fi/opm/koulutus/?lang=en>

Organisation for Economic Co-Operation and Development. 1996a. Employment and Growth in the Knowledge-Based Economy. Paris: OECD.

Organisation for Economic Co-Operation and Development. 1996b. Measuring What People Know: Human Capital Accounting for the Knowledge Economy. Paris: OECD.

Organisation for Economic Co-Operation and Development. 1998. Human Capital Investment: An International Comparison. Paris: OECD.

Organisation for Economic Co-Operation and Development. 2001. The Well-Being of Nations: The Role of Human and Social Capital. Paris: CERI.

Organisation for Economic Co-Operation and Development. 2002. Education Policy Analysis. Paris: OECD.

Organisation for Economic Co-Operation and Development. 2005. Teachers Matter. Paris: OECD.

Ozga, J., Lingard, B. 2007. Globalisation, Education Policy and Politics. In B. Lingard, B., Ozga, J. (Eds.), The Routledge Falmer Reader in Education Policy and Politics. Abingdon: Routledgefalmer, 65-82.

Pissarides, C. 2000. Human Capital and Growth. Paris: OECD.

Puaca, G. 2011. Imperatives for 'Right' Educational Choices in Swedish Educational Policy. Paper Given at the European Conference on Educational Research, Berlin, Germany.

Regeringskansliet. 2011. Sweden's 2011 Report on the Implementation of the Strategic Framework for European Co-Operation In Education and Training [online], May, 2011 <http:/ / ec.europa.eu/education/lifelong-learninpolicy/doc/natreport11/sweden_en.pdf>

Regjeringen. 2009. Education and Research [online], May, $2011<\mathrm{http}$ // www.regjeringen.no/en/topics/education-and-research.html?id=930>

Rikowski, G. 1999. Education, Capital and the Transhuman. In Hill, D., Mclaren, P., Cole, M., Rikowski, G. (Eds.), Postmodernism In Educational Theory. London: The Tuffnell Press, 50-85.

Rikowski, G. 2001. After the Manuscript Broke off: Thoughts on Marx, Social Class and Education [online], May, 2011 <http://www.leeds.ac.uk/educol/documents/00001931.htm>

Rikowski, G. 2005. Silence on the Wolves: What is Absent in New Labour's Five Year Strategy for Education. Brighton: University of Brighton.

Rikowski, G. 2007. Forms of Capital: Critique of Bourdieu on Capital [online], May, 2011 <http: / /www.flowideas.co.uk/ print.php?page=314>

Rizvi, F., Lingard, B. 2010. Globalizing Education Policy. Abingdon: Routledge.

Room, G. (Ed.). 2005. The European Challenge: Innovation, Policy Learning and Social Cohesion in the new Knowledge Economy. Bristol: The Polity Press. 
Rose, N. 1999. Powers of Freedom. Cambridge: Cambridge University Press. Ruane, C. 2008. Minister Launches 'Every School a Good School: A Strategy for Raising Achievement in Literacy and Numeracy" [online], May, 2011 <http:/ www.northernireland.gov.uk/news/news-de/news-de-230608-ministerlaunchesevery.htm> Schmied, C. 2010. Investing in Human and Social Capital: New Challenges [online], May, 2011 <http://www.bmukk.gv.at/ministerium/ministerin/reden/oecdopening. $\mathrm{xml}>$

Schultz, T. 1960. Capital Formation by Education. In The Journal of Political Economy, 68 (6): 571-583.

Schultz, T. 1961. Investment In Human Capital. In The American Economic Review, 51 (1): $1-17$.

Schultz, T. 1962. Reflections on Investment In Man. In The Journal of Political Economy, 70 (6): 1-8.

Schultz, T. 1967. Investment in Poor People. Washington DC: US Department of Labor.

Schultz, T. 1971. Education and Productivity. Washington DC: National Commission on Productivity.

Schultz, T. 1981. Investing in People. Berkeley, CA: University of California Press.

Scottish Government. 2011a. Our Purpose [online], May, $2011<$ http://www.scotland.gov.uk/about/scotperforms/purposes>

Scottish Government. 2011b. Skills for Scotland [online], May, $2011<\mathrm{http}$ //www. scotland.gov.uk/about/strategic-objectives/smarter>

Sen, A. 1999. Development as Freedom. Oxford: Oxford University Press.

Skolverket. 2006. Curriculum for the Compulsory School System, the Pre-School Class and the Leisure-Time Center ( Lpo 94). Stockholm: Skolverket.

Slovak Government. 2010. Civic Responsibility and Co-Operation. Manifesto of the Government of the Slovak Republic for the Period 2010-2014. [online], May 2011 <http://www.docstoc.com/docs /56891990/the-manifesto-of-the-government-ofthe slovakrepublic>

Undervisnings Ministeriet. 2007. Denmark's Strategy for Lifelong Learning. Copenhagen: The Authors.

Weiss, A. (1995). Human Capital V. Signalling Explanations of Wages. In The Journal of Economic Perspectives, 9(4): 133-154.

\section{Author:}

Donald Gillies, Ph.D., Senior Lecturer

University of Strathclyde

Faculty of Humanities \& Social Sciences

School of Education

Jordanhill Campus

G13 1PP Glasgow

UK

Email: donald.gillies@strath.ac.uk 